\title{
Causality and Long-term Analysis between Investments and Exports in Turkey
}

\author{
Türkiye'de Yatırımlar ve İhracat Arasındaki Nedensellik ve Uzun Dönem \\ Analizi
}

\begin{abstract}
This study examined causality association and short-and long-term relationship between investments and exports in Turkey for the period of 1980-2019. After detecting that series of investment and export are stationary at first differences based on KPSS stationarity test, a cointegration test was implemented by employing the autoregressive distributed lag (ARDL) bound test, the results of which disclosed that investments and exports in Turkey are co-integrated and move together over the long-term. The long-term coefficient estimation findings showed that investments positively and statistically significantly affect exports over the long-term. In other words, an increase in the investment level by $1 \%$ induced increase in the export level by $0.13 \%$ over the long-term. Meantime the estimated model had no problems with regard to autocorrelation, heteroscedasticity, normality, and model specification. Finally, the causality test results indicated that there was only a one-way causality relationship running from the investments to the exports.
\end{abstract}

Öz

Bu çalışma yatırımlar ve ihracat değişkenleri arasındaki nedensellik ve kısa-uzun dönem ilişkiyi Türkiye'nin 1980-2019 dönemi verileri ile açıklamaktadır. KPSS durağanlık testine bağh olarak yatırımlar ve ihracat serilerinin birinci farklarının durağan olduğuna ulaşılmasından sonra ARDL sınır testini istihdam ederek bir eş bütünleşme testi uygulanmıştır. $B u$ analiz sonuçlarn Türkiye'de yatırımlar ve ihracat değişkenlerinin eş bütünleşik olduğu ve uzun dönemde birlikte hareket ettiği sonucuna ulaşılmıştır. Uzun dönem katsayı tahmin bulguları uzun dönemde yatırımları ihracatı pozitif yönlü istatistiksel olarak anlaml etkileyeceğini göstermektedir. Başka bir deyişle, yatırımlardaki \%1'lik bir artışın, uzun dönemde ihracat seviyesinde \%0,13 kadar bir artışa neden olmaktadır. Ayrıca tahmin edilen model; oto korelasyon, değişen varyans, normallik ve model belirleme ile ilişkili problemlere sahip bulunmamaktadır. Sonuç olarak; nedensellik test sonuçları, yatırımlardan ihracata doğru tek yönlü bir nedensellik ilişkisi olduğu sonucuna ulaşmaktadır.

\section{Introduction}

In the literature, the contribution of international trade policies to economic growth has attracted the interest of policymakers and researchers. Theoretically, Adam Smith proposed the orthodox economic theory, and it was interpreted for the case of the trade and economic growth nexus. In his analysis, the trade of a country acts as a substantial contributor for the economic growth of the country, specifically in the context of developing and emerging economies. For example, the motivation here might be an export-led growth paradigm in which rapid export growth is accompanied by higher economic growth in national product (Behramian and Saliminezhad, 2020: 131-132). In this regard, the intersection between export and economic growth has raised essential questions among researchers (Waheed, Sarwar, and Dignah, 2020). The traditional classical approach, as well as the current liberal economists, have suggested that trade enhancement is an important channel through which export increases the probability of economic growth. If an economy can competitively develop specialized outputs for exporting markets, a strategy of export enhancement may be consistent with the general framework in the comparative advantage 
principle. In this regard, the move into exporting may lead subsequent advantages for community of the world due to cheaper prices, larger markets, increasing integration of internal and external countries, and enhanced income and employment levels. As a result, it is possible that the strategy of moving into export markets contributes to the process of economic development (Majeed, Ahmad, and Khawaja, 2006: 1265).

Thus, it can be expected that exports potentially provide a higher employment level, increase productivity, and consequently, promote economic growth (Love and Mansury, 2009; Feenstra, Ma and $\mathrm{Xu}, 2019$; Sasahara, 2019). Generally, many empirical papers have analyzed the exportproductivity nexus (Vu, Holmes, Tran and Lim, 2016; Zhou, 2020; Dalgıç, Fazlıŏlu and Gasiorek, 2021; Esaku, 2021; Gkypali, Love and Roper, 2021), and the empirical findings have shown that export has a significant positive impact on a firm's productivity. For example, Yang and Chen (2012) investigated the relationship between exporting and productivity for Indonesian manufacturing firms. Their empirical analyses showed that an increase in exporting could positively affect productivity. This result supported the view of learning-by-exporting hypothesis. On the other hand, an attempt to investigate the impact of exports on aggregate productivity growth was undertaken by Fu (2005), who hypothesized that one-channel higher exports positively affect the productivity level. This paper used a panel of Chinese manufacturing sectors for the period of 19901997. The paper demonstrated that the estimated coefficient of exports was not statistically significant for the productivity level, while they found significantly more efficient results in the exports sectors than in the non-exports sectors. In the export-employment literature, an exportoriented policy might play an important role for employment level in a country. A substantial topic is whether larger access to export markets leads to a higher employment level. According to the large body of this literature, many papers have demonstrated that exports have an established connection with employment (Leclair, 2002; Dones Tacero, Heredero de Pablos and Ruesga Benito, 2017), while other researchers have frequently examined the employment effects of foreign trade (Fufita and James, 1997; Dessing, 2002; Abraham and Brock, 2003; Portella-Carbo, 2016; Güloğlu, Bayar and Tokpunar, 2020).

In this sense, according to the literature, it is possible to correlate exports with economic growth (Lee, 2011; Gokmenoglu, Sehnaz and Taspinar, 2015; Raiher, Do Carmo and Stege, 2017). For the case of The Association of Southeast Asian Nations (ASEAN) countries, Ahmad and Harnhirun (1995) investigated the causality relationship between exports and economic growth and used the annual data of the included variables covering the period of 1966-1990. The empirical results of the Granger causality test for Singapore showed that there is positive bi-directional causality between the variables, while there appears to be no evidence for other countries in the ASEAN region. In addition, Awokuse (2007) investigated the validity of export-led growth (ELG) and growth-led import (GLE) hypotheses by covering the data from 1993 to 2004 for the case of Bulgaria, Czech Republic, and Poland. The findings mentioned that the ELG and GLE hypotheses were valid in Bulgaria, while the validity of the ELG hypothesis was supported in only the Czech Republic data. On the other hand, in Poland, the empirical findings indicated that there was no causal relationship between exports and economic growth. Thornton (1997) explored the causal linkages between exports and economic growth for the case of six European countries. The empirical results of the Granger causality analyses indicated that there was a positive uni-directional causal link from gross national product (GNP) to exports in Italy. Thus, the expansion of GNP is a leading contributor to exports. In addition to the ELG and GLE hypotheses, Ramos (2001) examined the validity of feedback hypothesis, in which the causality links between economic growth and trade were expected in both directions in Portugal over the period of 1865-1998. Tekin (2012) indicated that the explanations of the ELG and GLE hypotheses were different in the case of the least developed countries (LDCs). For example, it was found that the ELG hypothesis was valid for manufacturing and services-exporting LCDs, while exploring the GLE hypothesis in oil-exporting LCDs. Even though exports have effectively promoted economic growth, a very limited number of empirical papers have found a negative impact of exports on economic growth (Artega, Cardozo and Diniz, 
2020). For instance, Quaicoe, Aboagye, and Bokpin (2017) found that free-zone exports negatively affected economic growth in Ghana on quarterly time series data for 1998-2015.

Contrary to previous empirical literature analyzing the role of exports on the economic growth, the extensive empirical works focused on comparisons of the performance between exporters and non-exporters (Melitz, 2003; Aurangzeb, 2006; Okpara, 2009; Le and Valadkhani, 2014). According to Weeks (2001: 4), it was implied that exports mean foreign investment, while the non-export sector implies domestic investment. It is necessary to emphasize that much research has been motivated by large differences between exporters and non-exporters. According to the literature, it seems that the efficiency performance of exporting activities tends to have higher levels when compared to nonexporting activities. In an economic sense, exporters provide more specific benefits because exports are considered as a primary determinant of high economic growth due to new job creation, higher capital formation, and higher technological improvement (Bernard and Jensen, 1999: 1-2). A number of empirical studies have compared different dimensions of characteristics among exporters and non-exporters at the firm, country, and regional level (Aw and Hwang, 1995; Bernard and Wagner, 1997). Greenaway, Guariglia and Kneller (2007) explored how financial health showed an alteration across exporters and non-exporters using panel data on a sample of 9292 UK manufacturing firms over the period 1993-2003. They found that financial health was stronger for the exporters of UK manufacturing firms when compared to non-exporters. Girma, Görg and Strobl (2004) compared the performance of domestic plants, domestic exporters, and domestic multinationals using an annual survey of large manufacturing plants in Ireland for the period of 2004. They used labor productivity and profitability as a measure of plant performance. Their coefficients for comparison of the three types of plants indicated that domestic multinational plants have higher performance when compared to domestic exporters and non-exporters. Moreover, they did not find a significant difference in the plant performance between domestic plants and domestic exporters. In addition, there have been many empirical papers that have established the existence of relationship between exports and non-export sectors (Ibrahim and MacPhee, 2003; Dreger and Herzer, 2013; Debnath, Roy, Dasgupta and Mazumder, 2014). For example, Hutchison and Singh (1992) researched the dynamic causal relationships between the growth of export and non-export sectors by studying data ranging from 1950-1985 for 34 countries. Based on the empirical time series analysis results, the paper illustrated that there were significant positive externality effects and causal links from export growth to non-export output growth for developing economies in the 34 countries. Chadra Parida and Sahoo (2007) aimed to examine the impact of exports and manufacturing exports on non-export GDP in 4 South Asian economies using the Pedroni panel cointegration method over the period of 1980-2002. The paper considered that the non-exports real GDP variable was one of the growth variables. The estimation results showed that exports could have increased the countries' nonexports level. Thus, there is evidence for the export-led and manufacturing export-led growth hypothesis.

Thus, the importance of the determinants of exports is due to the positive and direct impact of exports on economic growth. In this sense, despite the abundance of research analyzing the relationship between export and economic growth, the stability of investment at the macro level for export has been of little interest in the literature. Nevertheless, it can be seen that many existing studies in this literature focus generally on different types of investments such as foreign direct investments (FDIs) and firm-level investment.

Seen from a FDI perspective, in fact, countries concerned with magnitude of international distribution through exporting, such as China and India, have established exclusive export districts and have provided incentives for attracting foreign investments, such as tax reductions and enter to free or low-priced areas (Boly, Coniglio, Prota and Seric, 2014: 422). The empirical literature on exporting has widely emphasized the importance of FDIs (Aitken, Hanson and Harrison, 1997; Amighini and Sanfilippo, 2014). For instance, Sunde (2017), empirically investigated the causality between FDI and exports, and found a positive unidirectional causal association from FDI to exports in South Africa. Moreover, Anwar and Sun (2018) attempted to examine the effect of the presence of foreign firms on industry export quality in China's manufacturing sector. The results confirmed that 
the foreign presence enhances export quality in China. In addition, in the case of the oil-rich economies of the Gulf Cooperation Council (GCC) countries, Elheddad (2019) found strong evidence of positive effects of FDI on the private and public investments over the period of 2003-2013, by comparing greenfield and oil FDI inflows and outflows. In this regard, this positive connection between FDI and investments is significant for clarifying why investments lead to higher export levels, because FDI is important for exports. Therefore, it is expected that the higher anticipated FDI level increases investments, which increases the export level in a country. An issue debated in the literature is also the role of FDI in the productivity (Boghean and State, 2015; Liang, 2017; Lin, Du, Dong, Jin and Liu, 2020; Yu, Li, Yu and Li, 2021). For example, Li and Tanna (2019) analyzed the effect of FDI on the total factor productivity growth in 51 developing countries, covering the period of 1984-2010 and found that FDI had significantly a weak direct effect on the total factor productivity growth.

From a firm-level investment perspective, there are literature that have explored the relationship between firm-level investment and exports. In this sense, Liu and Lu (2015) analyzed the impact of firm investment on the likelihood of exporting using the National Bureau of Statistics of China from 1998-2007. They also employed the most comprehensive firm-level data in China by covering all governmental and non-governmental enterprises. The results showed that higher firm investments in China significantly increased the probability of exporting due to the positive effect of firm investments on firm productivity. When clarifying the connection between investment and a firm's export performance, some researchers have explored the positive impacts of investments on productivity (Gomes, Alves and Silva, 2018; Khanna and Sharma, 2018; Li, Miao and Zhang, 2021; Qiu, Wang and Geng, 2021). For example, Antonietti and Marzucchi (2014) focused on the following two-stage model to empirically analyze the connection between investments in environmentallyoriented equipment and a firm's export performance. Stage one is to investigate the effect of green tangible investment strategies on the total factor productivity, and stage two is the effect of productivity on the propensity and the intensity of exports based on the data of manufacturing firms in Italy from 2001 to 2006. The analysis results illustrated that the coefficient of investments in environmentally oriented equipment is statistically significant and positive, indicating that the green investment strategy leads to higher productivity, while the effect of productivity on the export performance is positive and statistically significant.

As described above, the importance of the determinants of exports is due to the positive and direct impact of exports on economic growth. In this sense, despite the abundance of research analyzing the relationship between export and economic growth, the stability of investment at the macro level for export has been of little interest in the literature. Therefore, this study considered how gross capital formation, as an indicator of investments, interacts with exports in Turkey. For this purpose, it was attempted to examine the direction of the causality and long-term association between the variables. In the empirical framework, the vector autoregression (VAR) Granger Causality/Block Exogeneity Wald test was adopted to examine the causal relationship, while the autoregressive distributed lag (ARDL) estimation method was employed to examine the short- and long-term association between the variables using an annual data set over the period of 1980 to 2019 . In this sense, this study makes three specific contributions to the literature, because it differs from the previous papers (Peluffo, 2016; Akcan, 2019). First, to measure investment, while economic literature analyzing the effect of investments on exports employed proxies like firm-level investments and FDI, employed herein was the gross capital formation variable at a macro level in the Turkish economy. Second, causality analysis was conducted via VAR Granger Causality/Block Exogeneity Wald tests and short- and long-term analyses were conducted via the ARDL estimation technique in Turkey. Third, the empirical analyses used richer and more current data.

The rest of the study is divided into four sections: section 2 presents the data and methodology, section 3 presents the empirical results, and section 4 concludes the study. 


\section{Data and Methodology}

This study empirically examines the direction of causality and the long-term association between investments and exports in Turkey by using an annual data of 1980 - 2019. Causality analysis was conducted by employing VAR Granger Causality/Block Exogeneity Wald Tests and short-term and long-term analyses were conducted by employing ARDL estimation method. We expect to find a positive impact of investments on exports owing to fact that an increase in investment level will result in an increase in the production capacity and thus in turn export capability of Turkey. We use gross fixed capital formation measured in terms of current US\$ as an indicator of investment level (INVEST) in Turkey and it is collected from WDI (World Development Indicators) of the World Bank. Exports of goods and services measured in terms of percentage of GDP are utilized as an indicator of export level (EXPORT) in Turkey and it is gathered from WDI of the World Bank. In all our analyses we used the logarithmic form of INVEST and EXPORT variables.

Firstly, we checked the stationarity of INVEST and EXPORT variables. Secondly, we implemented causality analysis between INVEST and EXPORT variables.

Thirdly an ARDL boundary test was performed to figure out if INVEST and EXPORT variables are co-integrated. Therefore, the following ARDL model was estimated:

$$
\begin{aligned}
\triangle E X P O R T_{t}= & \beta_{0}+\gamma_{p} \text { EXPORT }_{t-1}+\gamma_{1} \operatorname{INVEST}_{t-1} \\
& +\sum_{i=1}^{q} \delta_{i} \Delta E X P O R T_{t-i}+\sum_{i=0} \phi_{i} \Delta I N V E S T_{t-i} \\
& +\varepsilon_{t}
\end{aligned}
$$

In above equation, $\gamma_{0}$ and $\gamma_{1}$ show long-term coefficients; $\delta_{i}$ and $\phi_{i}$ represent short-term coefficients; $\Delta$ indicates first degree difference operator; $\beta_{0}$ stands for constant term of the models, and $\varepsilon_{t}$ symbolizes white noise error term of the model.

In regard to ARDL bound test, the null hypothesis of $H_{0}: \gamma_{0}=\gamma_{1}=0$ (i.e., INVEST and EXPORT variables are not co-integrated) is compared with the alternative hypothesis of $H_{1}: \gamma_{0} \neq \gamma_{1} \neq 0$ (i.e., INVEST and EXPORT variables are co-integrated). Any F-statistic value of ARDL boundary test above the upper limit at a particular significance level leads to accept $H_{1}$ hypothesis. However, any F-statistic value smaller than the lower limit at a particular significance level causes to accept $H_{0}$ hypothesis. On the other hand, any F-statistic value falls in between the lower and upper limits then it is impossible to make decision on co-integration.

Lastly, following error correction model was estimated to obtain short-term and long-term coefficients:

$$
\text { EXPORT }_{t}=\beta_{0}+\eta E C M_{t-1}+\sum_{i=1}^{p} \delta_{i} \Delta E X P O R T_{t-i}+\sum_{i=0}^{q} \phi_{i} \Delta \operatorname{INVEST}_{t-i}+\varepsilon_{t}
$$

In above equation, $\delta_{i}$ and $\phi_{i}$ represent the dynamic short-term coefficients; ECM stands for the error correction term; $\eta$ shows the speed of adjustment at which the series return back to long-term path in response to a shock taken place in short-term and it should be negative and statistically significant.

\section{Empirical Results}

We conducted Kwiatkowski-Phillips-Schmidt-Shin (KPSS) test to investigate the stationary of INVEST and EXPORT variables. The null hypothesis of the KPSS test claims the stationarity of series against to the alternative hypothesis asserting the non-stationary of series. In Table 1 we depict the findings of KPSS stationarity test for the case of "constant".

Table 1. KPSS Stationarity Test

\begin{tabular}{|c|c|c|}
\hline Variable & LM-Stat. & Critical Values \\
\hline \multirow{2}{*}{ EXPORT } & \multirow{2}{*}{0.833665} & $1 \%$ level: 0.739 \\
\cline { 3 - 3 } & & $5 \%$ level: 0.463 \\
\hline
\end{tabular}




\begin{tabular}{|c|c|c|}
\hline \multirow{3}{*}{ 1. Diff. EXPORT } & & $10 \%$ level: 0.347 \\
\hline \multirow{3}{*}{ INVEST } & \multirow{3}{*}{0.269381} & $1 \%$ level: 0.739 \\
\cline { 3 - 3 } & & $5 \%$ level: 0.463 \\
\cline { 3 - 3 } & \multirow{3}{*}{0.737584} & $10 \%$ level: 0.347 \\
\cline { 3 - 3 } & & $1 \%$ level: 0.739 \\
\cline { 3 - 3 } & & $5 \%$ level: 0.463 \\
\hline \multirow{3}{*}{ 1. Diff. INVEST } & \multirow{3}{*}{0.118208} & $10 \%$ level: 0.347 \\
\cline { 3 - 3 } & & $5 \%$ level: 0.739 \\
\cline { 3 - 3 } & & $10 \%$ level: 0.347 \\
\hline
\end{tabular}

With regard to KPSS test results, both INVEST and EXPORT variables are not stationary at levels, but they are stationary in first differences (i.e., I (1)).

Table 2 below gives the causality test results implemented via VAR Granger Causality/Block Exogeneity Wald Tests in which stationary forms of INVEST and EXPORT variables are utilized. The causality test result based on VAR $(2,2)$ where optimal lag length was decided by using AIC criterion implies that there is only one-way causality running from INVEST to EXPORT.

Table 2. Causality Test

\begin{tabular}{lc}
\hline Panel A: (Dependent variable: EXPORT) \\
\hline Chi-sq & Prob. \\
5.409974 & 0.0669 \\
\hline Panel B: (Dependent variable: INVEST) \\
\hline Chi-sq & Prob. \\
1.616473 & 0.4456 \\
\hline
\end{tabular}

Given the fact that ARDL boundary test is applicable for any level of integration lower than I(2) and INVEST and EXPORT variables are I(1), we are able to employ ARDL boundary test for cointegration analysis between INVEST and EXPORT variables.

Akaike criterion (AIC) was used to find out the optimal leg lengths for the model given in Equation 1. Table 3 displays the findings for twelve different ARDL models and the findings indicate that the best model in terms of optimal lag length is ARDL $(1,1)$ for the model given in Equation 1.

Table 3. Optimal Lag Length Selection for the Model in Equation 1

\begin{tabular}{llrrrrr}
\hline Model & LogL & AIC & BIC & HQ & Adj. R-sq & Specification \\
\hline 11 & 30.851659 & $\mathbf{- 1 . 4 5 1 4 4 1}$ & -1.27788 & -1.39004 & 0.797329 & ARDL(1, 1) \\
1 & 34.295597 & -1.421384 & -1.07307 & -1.29858 & 0.808548 & ARDL(3,3) \\
10 & 31.289221 & -1.421039 & -1.20347 & -1.34429 & 0.795881 & ARDL(1,2) \\
9 & 31.896036 & -1.399786 & -1.13855 & -1.30764 & 0.796095 & ARDL(1,3) \\
7 & 30.891410 & -1.399539 & -1.18184 & -1.32278 & 0.791444 & ARDL(2,1) \\
3 & 31.754308 & -1.392125 & -1.13089 & -1.30002 & 0.794527 & ARDL(3,1) \\
6 & 31.304862 & -1.36783 & -1.1066 & -1.27573 & 0.789474 & ARDL(2, 2) \\
5 & 32.048320 & -1.353963 & -1.04919 & -1.24651 & 0.791026 & ARDL(2,3) \\
2 & 32.031809 & -1.353071 & -1.04830 & -1.24562 & 0.790839 & ARDL(3,2) \\
12 & 24.896752 & -1.183608 & -1.05299 & -1.13756 & 0.728593 & ARDL(1,0) \\
8 & 24.943089 & -1.132059 & -0.95790 & -1.07066 & 0.721068 & ARDL(2,0) \\
4 & 25.511833 & -1.108748 & -0.89105 & -1.03200 & 0.721060 & ARDL(3,0) \\
\hline
\end{tabular}


In Table 4, ARDL bound test results were reported. As can be seen from the table, F-statistic value of 13.53604 exceeds the upper bound critical values at all significance levels and hence we can state that EXPORT and INVEST variables are co-integrated and they move together in the long-term.

Table 4. ARDL Bound Test

\begin{tabular}{|l|c|c|}
\hline \multirow{2}{*}{ F-statistic } & \multicolumn{2}{|c|}{ Critical Values } \\
\hline Significance & $\begin{array}{c}\text { I(0) Lower } \\
\text { Bound }\end{array}$ & $\begin{array}{c}\text { I(1) Upper } \\
\text { Bound }\end{array}$ \\
\hline $10 \%$ & 3.02 & 3.51 \\
\hline $5 \%$ & 3.62 & 4.16 \\
\hline $2.5 \%$ & 4.18 & 4.79 \\
\hline $1 \%$ & 4.94 & 5.58 \\
\hline
\end{tabular}

Table 5 below provides the long-term coefficient estimations. The results hint that investment level has a positive statistically significant long-term effect on investment level in Turkey. In other words, an increase in investment level by $1 \%$ leads to an increase in export level by $0.13 \%$ in the long-term in Turkey.

Table 5. Long-run Coefficient Estimations for ARDL(1,1) Model

\begin{tabular}{|l|l|l|l|}
\hline Variable & Coefficient & t-statistic & Prob. \\
\hline INVEST & 0.130756 & 2.520071 & 0.0164 \\
\hline Constant & -0.118599 & -0.090165 & 0.9287 \\
\hline
\end{tabular}

As indicated by Table 6, short-run coefficient of INVEST variable is negative and statistically significant. Meanwhile, the ECM coefficient estimation gets the anticipated negative sign and is statistically significant. As indicated by the diagnostic test results in Table 6 and CUSUM stability test in Figure 1, our ARDL $(1,1)$ model does not contain any autocorrelation, heteroscedasticity, normality, and model specification problem.

Table 6. Short-run Coefficient Estimations for ARDL(1,1) Model

\begin{tabular}{|c|c|c|c|}
\hline & Coefficient & t-Statistic & Prob. \\
\hline$\triangle I N V E S T_{t}$ & -0.259575 & -3.451691 & 0.0015 \\
\hline$E C M_{t-1}$ & -0.347729 & -6.551992 & 0.0000 \\
\hline \multicolumn{4}{|c|}{$\mathrm{ECM}=\mathrm{EXPORT}-(0.1308 * \mathrm{INVEST}-0.1186)$} \\
\hline \multicolumn{4}{|c|}{ Diagnostic Tests } \\
\hline \multicolumn{3}{|c|}{ Tests } & Test Value (Prob.) \\
\hline \multicolumn{3}{|c|}{ Breusch-Godfrey Serial Correlation LM Test } & $1.420004(0.2561)$ \\
\hline \multicolumn{3}{|c|}{ ARCH Heteroskedasticity Test } & $0.212797(0.6474)$ \\
\hline \multicolumn{3}{|c|}{ Ramsey RESET Test } & $0.395510(0.5336)$ \\
\hline \multicolumn{3}{|c|}{ Jarque-Bera Test } & $1.613702(0.446261)$ \\
\hline
\end{tabular}




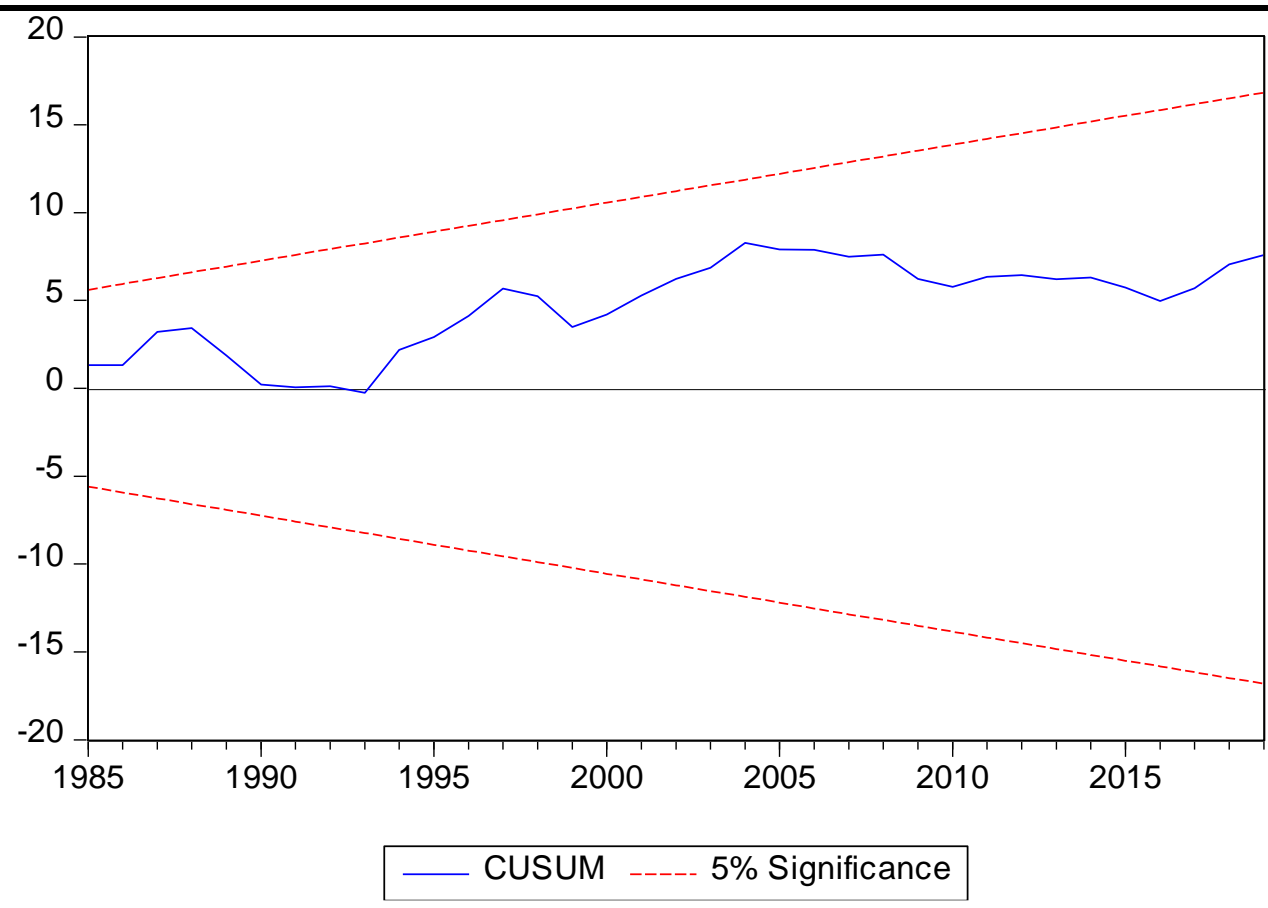

Figure 1. CUSUM Stability Test

\section{Conclusion}

In this study we empirically analyze causality relationship and short-term and long-term association between investment level and export level in Turkey for the period of 1980- 2019. Causality analysis was conducted via VAR Granger Causality/Block Exogeneity Wald Tests and short-term and long-term analyses were conducted via ARDL estimation technique.

A positive interaction between investments and exports was expected based on fact that an increase in investment level will lead to an increase in the production capacity and thus in turn export capability of Turkey.

After detecting that EXPORT and INVEST variables are stationary at first differences relied on KPSS stationarity test, a co-integration test by using ARDL bound test was conducted and the test findings imply that there is a co-integration relationship between EXPORT and INVEST variables. In other words, EXPORT and INVEST variables move together in the long-term.

The long-term coefficient estimation results reveal that investments have a positive statistically significant impact on exports in the long-term in Turkey and an increase in investment level by $1 \%$ leads to an increase in export level by $0.13 \%$. Moreover, the estimated model does not have any problem in terms of autocorrelation, heteroscedasticity, normality, and model specification. Lastly causality test results show that there exists just one-way causality relationship running from investments to exports.

\section{References}

Abraham, F., \& Brock, E. (2003). Sectoral employment effects of trade and productivity in Europe. Applied Economics, 35(2), 223-238

Ahmad, J., \& Harnhirun, S. (1995). Unit roots and cointegration in estimating causality between exports and economic growth: empirical evidence from the ASEAN countries. Economics letters, 49(3), 329-334.

Aitken, B., Hanson, G. H., \& Harrison, A. E. (1997). Spillovers, foreign investment, and export behavior. Journal of International economics, 43(1-2), 103-132.

Akcan, A. T. (2019). İhracat Değer Endeksi ve Yatırım İlişkisi: Türkiye Örneği (1982-2017). Girişimcilik ve Kalkınma Dergisi, 14(1), 11-18. 
Amighini, A., \& Sanfilippo, M. (2014). Impact of South-South FDI and trade on the export upgrading of African economies. World Development, 64, 1-17.

Antonietti, R., \& Marzucchi, A. (2014). Green tangible investment strategies and export performance: A firm-level investigation. Ecological economics, 108, 150-161.

Anwar, S., \& Sun, S. (2018). Foreign direct investment and export quality upgrading in China's manufacturing sector. International Review of Economics \& Finance, 54, 289-298.

Arteaga, J. C., Cardozo, M. L., \& Diniz, M. J. T. (2020). Exports to China and economic growth in Latin America, unequal effects within the region. International Economics, 164, 1-17.

Aw, B. Y., \& Hwang, A. R. M. (1995). Productivity and the export market: A firm-level analysis. Journal of development economics, 47(2), 313-332.

Awokuse, T. O. (2007). Causality between exports, imports, and economic growth: Evidence from transition economies. Economics letters, 94(3), 389-395.

Aurangzeb, A. Z. (2006). Exports, productivity and economic growth in Pakistan: a time series analysis. Lahore Journal of Economics, 11(1), 1-18.

Bahramian, P., \& Saliminezhad, A. (2020). On the relationship between export and economic growth: A nonparametric causality-in-quantiles approach for Turkey. The Journal of International Trade \& Economic Development, 29(1), 131-145.

Bernard, A. B., \& Jensen, J. B. (1999). Exceptional exporter performance: cause, effect, or both?. Journal of international economics, 47(1), 1-25.

Bernard, A. B., \& Wagner, J. (1997). Exports and success in German manufacturing. Weltwirtschaftliches Archiv, 133(1), 134-157.

Boghean, C., \& State, M. (2015). The relation between foreign direct investments (FDI) and labour productivity in the European Union countries. Procedia Economics and Finance, 32, 278-285.

Boly, A., Coniglio, N. D., Prota, F., \& Seric, A. (2014). Diaspora investments and firm export performance in selected sub-Saharan African countries. World Development, 59, 422-433.

Chandra Parida, P., \& Sahoo, P. (2007). Export-led growth in South Asia: a panel cointegration analysis. International Economic Journal, 21(2), 155-175.

Dalgıç, B., Fazlıoğlu, B., \& Gasiorek, M. (2021). Does it matter where you export and does productivity rise with exporting? The Journal of International Trade \& Economic Development, $1-26$.

Debnath, A., Roy, N., Dasgupta, P., \& Mazumder, N. (2014). On productivity differential of export composition: evidence from India. Journal of Chinese Economic and Foreign Trade Studies, 7(1), 38-50.

Dessing, M. (2002). The Impact of Trade on Employment in Eighteen Less-Industrialized Countries: An Econometric Analysis. Canadian Journal of Development Studies, 23(4), 743-774.

Dones Tacero, M., Heredero de Pablos, M. I., \& Ruesga Benito, S. M. (2017). Exports and employment in the Spanish economy: A repetitive pattern. Investigación económica, 76(301), 137-169.

Dreger, C., \& Herzer, D. (2013). A further examination of the export-led growth hypothesis. Empirical Economics, 45(1), 39-60.

Elheddad, M. (2019). Foreign direct investment and domestic investment: Do oil sectors matter? Evidence from oil-exporting Gulf Cooperation Council economies. Journal of Economics and Business, 103, 1-12.

Esaku, S. (2021). Export markets and firm productivity in Sub-Saharan Africa. Journal of African Business, 22(2), 254-273.

Feenstra, R. C., Ma, H., \& Xu, Y. (2019). US exports and employment. Journal of International Economics, 120, 46-58.

$\mathrm{Fu}, \mathrm{X}$. (2005). Exports, technical progress and productivity growth in a transition economy: a nonparametric approach for China. Applied economics, 37(7), 725-739.

Fujita, N., \& James, W. E. (1997). Employment creation and manufactured exports in Indonesia, 1980-90. Bulletin of Indonesian Economic Studies, 33(1), 103-115.

Girma, S., Görg, H., \& Strobl, E. (2004). Exports, international investment, and plant performance: evidence from a non-parametric test. Economics Letters, 83(3), 317-324. 
Gkypali, A., Love, J. H., \& Roper, S. (2021). Export status and SME productivity: Learning-to-export versus learning-by-exporting. Journal of Business Research, 128, 486-498.

Gokmenoglu, K. K., Sehnaz, Z., \& Taspinar, N. (2015). The export-led growth: A case study of Costa Rica. Procedia Economics and Finance, 25, 471-477.

Gomes, A. O., Alves, S. T., \& Silva, J. T. (2018). Effects of investment in information and communication technologies on productivity of courts in Brazil. Government Information Quarterly, 35(3), 480-490.

Greenaway, D., Guariglia, A., \& Kneller, R. (2007). Financial factors and exporting decisions. Journal of international economics, 73(2), 377-395.

Güloğlu, B., Bayar, G., \& Tokpunar, S. (2020). Effect of foreign trade on industrial employment: the case of Turkey. Applied Economics, 52(55), 6075-6089.

Hutchison, M., \& Singh, N. (1992). Exports, Non-Exports and Externalities: A Granger Causality Approach. International Economic Journal, 6(2), 79-94.

Ibrahim, I., \& MacPhee, C. R. (2003). Export externalities and economic growth. Journal of International Trade \& Economic Development, 12(3), 257-283.

Khanna, R., \& Sharma, C. (2018). Testing the effect of investments in IT and R\&D on labour productivity: New method and evidence for Indian firms. Economics Letters, 173, 30-34.

Le, V., \& Valadkhani, A. (2014). Are exporting manufacturing SMEs more efficient than nonexporting ones? Evidence from Australia's business longitudinal database. Economic Analysis and Policy, 44(3), 310-317.

Leclair, M. S. (2002). Export Composition and Manufacturing Employment in the US during the Economic Downturn of 1991-92. Economic Systems Research, 14(2), 147-156.

Lee, J. (2011). Export specialization and economic growth around the world. Economic systems, 35(1), 45-63.

Li, J., Miao, E., \& Zhang, J. (2021). The legal environment, specialized investments, incomplete contracts, and labor productivity. China Economic Review, 66, 101583.

Li, C., \& Tanna, S. (2019). The impact of foreign direct investment on productivity: New evidence for developing countries. Economic Modelling, 80, 453-466.

Liang, F. H. (2017). Does foreign direct investment improve the productivity of domestic firms? Technology spillovers, industry linkages, and firm capabilities. Research Policy, 46(1), 138-159.

Lin, B., Du, R., Dong, Z., Jin, S., \& Liu, W. (2020). The impact of foreign direct investment on the productivity of the Chinese forest products industry. Forest Policy and Economics, 111, 102035.

Liu, Q., \& Lu, Y. (2015). Firm investment and exporting: Evidence from China's value-added tax reform. Journal of International Economics, 97(2), 392-403.

Love, J. H., \& Mansury, M. A. (2009). Exporting and productivity in business services: Evidence from the United States. International Business Review, 18(6), 630-642.

Majeed, M. T., Ahmad, E., \& Khawaja, M. I. (2006). Determinants of exports in developing countries [with comments]. The Pakistan Development Review, 45(4 Part II), 1265-1276.

Melitz, M. J. (2003). The impact of trade on intra-industry reallocations and aggregate industry productivity. econometrica, 71(6), 1695-1725.

Okpara, J. O. (2009). Strategic choices, export orientation and export performance of SMEs in Nigeria. Management Decision, 47(8), 1281-1299.

Qiu, S., Wang, Z., \& Geng, S. (2021). How do environmental regulation and foreign investment behavior affect green productivity growth in the industrial sector? An empirical test based on Chinese provincial panel data. Journal of Environmental Management, 287, 112282.

Quaicoe, A., Aboagye, A. Q., \& Bokpin, G. A. (2017). Assessing the impact of export processing zones on economic growth in Ghana. Research in International Business and Finance, 42, 1150-1163.

Peluffo, A. (2016). The role of investments in export growth. Small Business Economics, 47(1), 115137.

Portella-Carbó, F. (2016). Effects of international trade on domestic employment: an application of a global multiregional input-output supermultiplier model (1995-2011). Economic Systems Research, 28(1), 95-117. 
Raiher, A. P., do Carmo, A. S. S., \& Stege, A. L. (2017). The effect of technological intensity of exports on the economic growth of Brazilian microregions: A spatial analysis with panel data. EconomiA, 18(3), 310-327.

Ramos, F. F. R. (2001). Exports, imports, and economic growth in Portugal: evidence from causality and cointegration analysis. Economic modelling, 18(4), 613-623.

Sasahara, A. (2019). Explaining the employment effect of exports: value-added content matters. Journal of the Japanese and International Economies, 52, 1-21

Sunde, T. (2017). Foreign direct investment, exports and economic growth: ADRL and causality analysis for South Africa. Research in International Business and Finance, 41, 434-444.

Tekin, R. B. (2012). Economic growth, exports and foreign direct investment in Least Developed Countries: A panel Granger causality analysis. Economic modelling, 29(3), 868-878.

Thornton, J. (1997). Exports and economic growth: Evidence from 19th Century Europe. Economics Letters, 55(2), 235-240.

Vu, H. V., Holmes, M., Tran, T. Q., \& Lim, S. (2016). Firm exporting and productivity: what if productivity is no longer a black box. Baltic Journal of Economics, 16(2), 95-113.

Waheed, R., Sarwar, S., \& Dignah, A. (2020). The role of non-oil exports, tourism and renewable energy to achieve sustainable economic growth: What we learn from the experience of Saudi Arabia. Structural Change and Economic Dynamics, 55, 49-58.

Weeks, J. (2001). Exports, foreign investment and growth in Latin America (No. 117). Working Paper Series.

Yang, C. H., \& Chen, Y. H. (2012). R\&D, productivity, and exports: Plant-level evidence from Indonesia. Economic Modelling, 29(2), 208-216.

Yu, D., Li, X., Yu, J., \& Li, H. (2021). The impact of the spatial agglomeration of foreign direct investment on green total factor productivity of Chinese cities. Journal of Environmental Management, 290, 112666.

Zhou, C. (2020). The effects of outward FDI and export on firm productivity in emerging markets: Evidence from matching approach. Economics Letters, 195, 109462. 